\title{
The ILO's Contribution to Improving the Welfare of Workers Globally, Especially in Asia and Africa
}

\author{
Duengphan Kharchani ${ }^{1}$, Rirkrit Haripitak ${ }^{1}$, Cinnakorn Burirat ${ }^{1}$ \\ Corresponding Email: due.krchanphani11@gmail.com \\ ${ }^{1}$ Student of Faculty of Social Sciences, Chiang Mai University, Thailand \\ Received: March 10, 2021 \\ Received in Revised: April 7, 2021 \\ Accepted: April 21, 2021
}

\begin{abstract}
The following essay addresses labour problems in a number of Asian and African nations. Additionally, the ILO's role in resolving this labor problem is critical due to the conditions in many countries worldwide. According to the 2014 Global Slavery Index, India is first in terms of modern global slavery, with a high rate of modern slavery, especially in the recruitment of jobs with promises of non-existent work that are then sold for profit. As a result, it is important for the ILO to resolve the problem of labor welfare. The ILO's primary goal is to improve labor welfare. The ILO has taken many measures, including: ratifying the United Nations Convention on the Protection of the Rights of All Migrant Workers and Members of Their Families; and Collaborating with many Asian countries to secure migrant workers' interests, conducting activities in support of migrant workers; developing services in support of migrant workers.
\end{abstract}

Keywords: Labor, ILO, Welfare

\section{Introduction}

Jobs is not a recent concern in many Asian countries; it has existed for a long period of time, and a major factor is a shortage of work and many other issues. As seen through the lens of manpower growth, the issue at hand is not isolated; rather, it is influenced by a variety of variables, including schooling, health, environment, and services, and as a result, resolving manpower issues requires a cross-sector strategy. Due to the difficulties of finding employment in their home nation, people in many Asian countries have migrated to countries with a reputation for job creation. Globalization has resulted in an increase in the flow of citizens between countries.

The growing number of employees in many Asian countries who work abroad is one of the consequences of the country's labor shortage (Henderson \& Tulloch, 2008; Naicker et al., 2009). As a result, being a foreign worker is one of the alternatives adopted by several residents of many Asian countries in order to support their families. Additionally, the nation profits from the arrival of jobs in many Asian nations, which has grown to be the second largest earner of foreign exchange after the oil and gas industry (oil and gas). According to Bank data from several Asian countries, foreign exchange provided by the placement of staff in several Asian countries abroad reached USD 6.6 billion in 2008, USD 6 billion in 2009, and USD 3.3 billion up to Semester I 2010 in 2010.

Malaysia, Taiwan, Saudi Arabia, Hongkong, Singapore, the United Arab Emirates, Brunei Darussalam, Qatar, South Korea, and the United States are the primary destinations for migrant workers from many Asian countries. On the one hand, the vast number of migrant workers in many Asian countries employed abroad has a positive effect, namely alleviating some of the domestic unemployment crisis, but it also has a negative effect, namely inhuman treatment of 
migrant workers. Migrant workers in many Asian countries often face systematic abuse, which begins with enrollment, recruiting, selection, and termination. In a thesis on 1, the author cited an Ecosoc Rights et al., Jakarta, 2010 text on Manpower.

The Center for Research and Development and Information on Labor Agencies in Placement and Protection of Workers in several Asian countries in 2013 was the source of the results. retrieved on January 19, 2017 The Consortium for the Protection of Migrant Workers discovered abuse against migrant workers in many Asian countries. The labour migrants in many Asian countries operate in the Asia-Pacific and Middle East. The majority of abuse and degradation is directed at female migrant employees, who experience extortion, physical violence, illness, theft, unlawful recruiting, sexual discrimination, unilateral termination of jobs, unpaid wages, and human trafficking, among other types of slavery.

\section{ILO Concept in Improving Workers' Welfare}

This organisation is founded on the philosophical tenet that total and permanent harmony can be reached only by a commitment to social justice. Respect for human rights, a fair standard of life, humane working practices, employment prospects, and economic stability are also critical components of social justice. The ILO was established with the mission of promoting social justice for all citizens, especially workers and laborers (Rodgers et al., 2009 Compa, 2004; Tapiola \& Swepston, 2010). Apart from developing universal labour practices, the ILO also serves as a shooting and training scheme. As a result, the ILO's missions are as follows: (1) Protecting workers' rights; (2) Expanding job opportunities; and (3) Improving workers' / laborers' quality of living.

The overarching goal of the ILO alliance is to advance the cause of decent work at the national level, assisting voters in making this idea a fact for both man and woman. A vast network of offices located in Africa, Asia, Latin America, Central Europe, Eastern Europe, and the Middle East offers strategic assistance on policy challenges and assists in the creation and execution of development programs.

\section{Welfare Conditions of Workers in Asian and African Countries}

According to 2010 International Labor Organization (ILO) numbers, there are over 52 million domestic workers worldwide. Domestic employees make up roughly 83 percent of this community. This is an indication of a nation with a large number of domestic staff in many Asian nations. According to ILO data from the National Job Units, the country employed approximately 2,555,000 domestic employees in 2012. 63\% of this total, or 1,609,650, are domestic workers who operate seven days a week, showing that domestic workers' working standards in certain Asian countries are substandard.

According to 2014 research on modern global slavery or the Global Slavery Index, India ranks first, with a high rate of modern slavery, especially in the recruitment of workers that do not exist, which are then sold for forced labour, homework, and stair work, among other things. Similarly, in many Asian nations, including those with the highest prevalence of slavery, it is ranked eighth with the highest number of slaves out of 167 countries, which hire domestic workers without granting them freedom. In this situation, the foreign party believes that working as a domestic worker is comparable to becoming a slave, despite the reality that domestic workers and slaves are distinct terms. This is because domestic workers have a more respectable role or career because they are both useful and free of exploitation, in contrast to slaves, which are not a profession. 


\section{The Role of the ILO in Improving the Welfare of Workers Globally}

Developing Conventions on Foreign Jobs With the ratification of the International Labour Organization's Declaration on Fundamental Principles and Rights at Work in 1998, ILO member countries agreed to extend a collection of labor conditions to the applicable conventions. This principles are a fundamental component of civil rights and the very definition of good job.

1975 Convention on Migrant Workers (Additional Provisions) (No. 143) Conventions No. 143 addresses the issue of forced migration in part I, and fair opportunities and justice in part II. Countries that have ratified this convention can recognize the whole instrument or a portion of it. States parties to this Convention are required to protect the basic human rights of all migrant workers.

Additionally, they would halt illegal migration and human trafficking. Additionally, States parties can develop and enact legislation to guarantee fair protection of jobs and labor, social welfare, labor unions, and cultural rights. This Convention requires the enforcement of fair employment protections on migrant labor entry, labor union privileges, cultural rights, and person and collective freedoms. National policies required by this convention should not only encourage but also guarantee fair opportunities and care in jobs and profession for migrant workers and their family members living in the country where they are lawfully employed (Man, 2004; Satterthwaite, 2005; Ross, 2007; Romero-Ortuño, 2004).

\section{United Nations Convention on the Protection of the Rights of All Migran Workers and Member of the Families}

'90 The International Convention on the Protection of the Rights of All Foreign Workers and Members of Their Families made a significant breakthrough by establishing that individuals who qualify as migrant workers under its terms are entitled to human rights regardless of their legal status. This Convention refers to all foreign workers and their dependents, regardless of gender, nationality, colour, language, faith, political opinion or other opinion, national origin, racial origin, ethnic origin, marital status, birth, or other sex. Security extends to all stages of relocation, including those preceding departure, departing, transiting, staying, working, and returning to the country of origin.

Part VI of the Convention imposes on states a series of responsibilities that are just, equitable, humanitarian, and centered on migrants and their communities. These conditions apply to the formulation of migration strategies; the sharing of knowledge with other state parties; the distribution of information about policies, rules, and regulations to businesses, employees, and their organizations; and the assistance provided to migrant workers and representatives of their families. Additionally, the Convention specifies a set of guidelines governing the recruiting of foreign workers and their relocation to their home countries. Additionally, it outlined the measures necessary to tackle irregular and illegal migration.

\section{Cooperating with Other Asian Countries to Protect Migrant Workers' Rights}

Since 12 June 1950, when the JOM FISIP Vol. 4 No. 2 - October 2017 joined the ILO, Asian countries and the ILO have collaborated together to encourage decent work for everyone. The ILO has worked to empower and defend migrant workers in Indonesia by establishing relationships with a variety of stakeholders, including government agencies, labor unions, migrant workers' and domestic workers' organisations, and civil society groups. several Asian nations, as well as in the countries of departure.

The ILO has undertaken a variety of programs, through a variety of initiatives, to support the government in its attempts to improve migrant worker rights and fight forced labour and 
trafficking. Ten in various Asian countries Since 2004, drafts on workers' privileges and working practices have been drafted with the assistance of ILO technicians. Five failed efforts to have this bill on the parliamentary agenda have been made.

However, in 2010, this bill was elevated to a national priority in the DPR's national legislative program and is now set for discussion in parliament. National reform debates erupted in 20102011, and support for rewriting this bill continues to be a political focus in parliament. In 2009, the governments of many recently elected Asian countries recognised that the framework for placing and protecting jobs abroad should also be improved. To that end, the ILO has worked with the government to ensure that the problem of migrant workers remains a focus in both the National Medium-Term Development Plan 2010-2014 and the Ministry of Manpower and Transmigration's Strategic Plan 2010-2014.

The government also worked to improve the legal structure for job placement and safety, including by amending Law No. 39 of 2004 on Worker Placement and Protection Abroad. The ILO offers professional assistance and financial resources to a variety of organizations in many Asian countries that work with labor migration. Public campaigns and stakeholder forums culminated in the President's acceptance of the law's revision. This agreement initiates substantive public debates between the government and parliament on the planned reform of the legislation, to which appropriate stakeholder groups are encouraged to contribute (the President's mandate to amend Law 39/2004 was signed on 8 August 2012). This amendment to the law was therefore incorporated into the 2012 National Legislation Program.

This meeting would address and debate five issues described as significant barriers to migration between Asia and Arab countries, including equal recruitment, decent job and working standards, applicant and worker skills, and returning worker skills, enhanced development effects of migration, and international collaborations and cooperation. Additionally, the meeting allowed participants to exchange perspectives and discuss next steps toward achieving inclusive migration between Asian and Arab countries.

\section{Conducting Campaigns Related to Migrant Workers}

The ILO improves migrant workers' rights and visibility by conducting a series of large-scale advertising programs to increase consciousness and inform the general public. This initiative aims to increase public knowledge of migrants' rights and working conditions, especially domestic workers and workers in many Asian countries, as well as the importance of labour protections such as job contracts, salaries, vacations, working hours, social security, and housing conditions.

The ILO hopes that these efforts can increase awareness, appreciation, and recognition of domestic workers' rights as workers. Additionally, the ILO, in cooperation with national and foreign radio and television news networks, has undertaken a number of radio initiatives and broadcasting activities on migrant workers' rights and working conditions through immersive talk shows and live broadcasts. Radio is the most cost-effective way to meet the greatest number of citizens available.

\section{Developing Programs for Migrant Workers}

(1) In many Asian nations, decent work programs for migrant workers In many Asian countries, decent employment programmes for migrant workers are currently focusing on a variety of priority fields, including job development, labour relations, and social security. These areas are informed by the socioeconomic background, national goals, the ILO mandate, and the ILO constituents' existing priorities. One of the foundations of the International Labour Organization's National Decent Work Program for a number of Asian countries Labor 
migration for security is a critical component of this pillar and is accomplished by the advancement of legal and regulatory mechanisms, counselling and empowerment, as well as tailored efforts to solve problems of forced labor and trafficking. ILO activities on labour mobility have taken place as a result of ideas exchanged about the importance of migrant worker security. (2) Program of Social Security The ILO Jakarta social protection program's primary goal is to help the government and ILO's social allies, including employers' and workers' associations, strengthen their capacity to develop and execute social protection policies and services. The primary policy for 2012 was to promote the Social Protection Floor (LPS), in compliance with ILO Recommendation No. 202, which was implemented at the ILC's 101st session in 2012. This 202 conducts studies and provides social protection focused on consultation in order to expand social care and job outreach to disadvantaged populations and historically unreached populations.

\section{Conclusion}

Becoming an overseas worker is one of the solutions employed by certain people in a number of Asian countries in order to provide for their family's needs. Additionally, the nation profits from the arrival of jobs in many Asian nations, which has grown to be the second largest earner of foreign exchange after the oil and gas industry (oil and gas). The ILO's Position in Globally Improving Workers' Welfare, Developing Conventions on Foreign Jobs Since the ILO adopted the Declaration on Fundamental Principles and Rights at Work in 1998, member countries of the ILO voted to introduce a set of labour standards-related conventions. This principles are a fundamental component of civil rights and the very definition of good job.

\section{References}

Compa, L. A. (2004). Justice for All: The Struggle for Worker Rights in China. Available From: https://ecommons.cornell.edu/handle/1813/74298

Henderson, L. N., \& Tulloch, J. (2008). Incentives for retaining and motivating health workers in Pacific and Asian countries. Human resources for health, 6(1), 1-20.

Man, G. (2004, June). Gender, work and migration: Deskilling Chinese immigrant women in Canada. In Women's studies international forum (Vol. 27, No. 2, pp. 135-148). Pergamon.

Naicker, S., Plange-Rhule, J., Tutt, R. C., \& Eastwood, J. B. (2009). Shortage of healthcare workers in developing countries--Africa. Ethnicity \& disease, 19(1), 60.

Rodgers, G., Lee, E., Swepston, L., \& Van Daele, J. (2009). The International Labour Organization and the quest for social justice, 1919-2009.

Romero-Ortuño, R. (2004). Access to health care for illegal immigrants in the EU: should we be concerned?. European journal of health law, 11(3), 245-272.

Ross, A. (2007). Nice work if you can get it: The mercurial career of creative industries policy. Work Organisation, Labour and Globalisation, 1(1), 13-30.

Satterthwaite, M. L. (2005). Crossing borders, claiming rights: using human rights law to empower women migrant workers. Yale Hum. Rts. \& Dev. LJ, 8, 1.

Tapiola, K., \& Swepston, L. (2010). The ILO and the Impact of Labor Standards: Working on the Ground after an ILO Commission of Inquiry. Stan. L. \& Pol'y Rev., 21, 513. 